This is a postprint version of the following published document:

Veiga, M.H. y Ramos, S. (2013). Oil price asymmetric effects:

answering the puzzle in international stock markets. Energy Economics, v. 38, pp. 136-145. Avalaible in:

http://dx.doi.org/10.1016/j.eneco.2013.03.011

(c) Elsevier

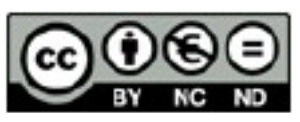

This work is licensed under a Creative Commons Attribution-NonCommercialNoDerivatives 4.0 International License. 


\title{
Oil price asymmetric effects: Answering the puzzle in international stock markets is
}

\author{
Sofia B. Ramos ${ }^{\mathrm{a}, *}$, Helena Veiga ${ }^{\mathrm{b}, \mathrm{c}}$ \\ a Business Research Center/UNIDE, Instituto Universitario de Lisboa (ISCTE-IUL), Avenida das Forças Armadas, 1600-083 Lisboa, Portugal \\ ${ }^{\mathrm{b}}$ Universidad Carlos III de Madrid (Department of Statistics and Instituto Flores de Lemus), C/Madrid 126, 28903 Getafe, Spain \\ c BRU/UNIDE, Avenida das Forças Armadas, 1600-083 Lisboa, Portugal
}

\section{A R T I C L E I N F O}

\section{Article history:}

Received 11 November 2011

Received in revised form 20 March 2013

Accepted 23 March 2013

Available online 29 March 2013

\section{JEL classification:}

C23

G15

Q43

Keywords:

Asymmetric effects

International stock markets

Oil prices

Panel data

Oil price volatility

\begin{abstract}
A B S T R A C T
Although studies have found an asymmetric pattern in the response of aggregate output to oil price changes, parallel studies in stock markets have not been conclusive about their existence. This paper finds evidence that effects for oil-importing and oil-exporting countries run in opposite directions. Oil price hikes have a negative effect on the stock markets of oil-importing countries, while the impact is positive for the stock markets of oil-exporting countries. Statistical tests support the presence of asymmetric effects only in oil-importing countries. Oil price volatility has a negative impact in stock markets of oil-importing countries and positive in oil-exporting countries. Moreover, oil volatility seems to be affected asymmetrically by oil price changes. Oil price drops increase oil volatility more than oil price hikes do. Overall, the evidence seems to support that falls in oil prices do not impact stock markets because their positive effects are offset by negative effects of oil price volatility, canceling out effects for oil-importing countries.
\end{abstract}

\section{Introduction}

The importance of energy costs to economic growth has motivated research to study the economic impact of oil price changes. In his pioneer work, Hamilton (1983) shows that oil price hikes accounted partially for every U.S. recession after World War II. Bernanke (1983) and Pindyck (1991) models explain that large oil price movements increase uncertainty about future prices, causing delays in business investments. Though oil price rises have negative effects on gross domestic product (GDP), strikingly, drops have not been found to stimulate aggregate output (see, for instance Mork, 1989; Mork et al., 1994), which has been commonly named in the literature as the asymmetric puzzle (see Ferderer, 1996).

Stock markets are commonly seen as bellwethers of the economy anticipating changes in the business activity (Fama, 1990; Schwert, 1990). Thus although studies like Sadorsky (1999), Basher and

\footnotetext{
We thank two referees and seminar participants at the 8th International Conference on European Energy Markets, 2011 European Financial Management Association, 18th Conference on the Multinational Finance Society, 17th International Conference on Computing in Economics and Finance-Society for Computational Economics, 6th Portuguese Financial Network and XXXV Simposio de la Asociación Española deEconomía (SAEe), for helpful comments. The authors acknowledge financial support from Fundação para a Ciência e Tecnologia PEst-OE/EGE/UI0315/2011 and from the Spanish Ministry of Education and Science, research projects ECO2009-08100, MTM2010-17323 and ECO2012-32401.

* Corresponding author. Tel.: + 351 217903000; fax: + 351217903072.

E-mail address: sofia.ramos@iscte.pt (S.B. Ramos).
}

Sadorsky (2006), Cong et al. (2008), Nandha and Faff (2008), and Park and Ratti (2008) have tried to find a similar asymmetric impact of oil price changes in stock markets, the evidence was mixed.

One shortcoming in the previous literature is a failure to address the role of oil price volatility in stock markets. Yet oil price volatility is likely to affect asymmetry because volatility can be a transmission mechanism itself. Uncertainty in future oil costs causes companies to postpone investments (Bernanke, 1983), because firms are uncertain whether the fall in energy prices is permanent or transitory. ${ }^{1}$ Ferderer (1996) adds that the interaction of oil volatility and oil price changes might create offsetting effects. He hypothesizes that if negative oil price changes affect oil price volatility positively, and if oil price volatility has a negative effect on the economy, the effects would offset and create an asymmetric response to oil price changes. Therefore, part of the asymmetric relations between oil price changes and output growth found in macroeconomic studies could be explained by the response of oil price volatility to oil price changes. Moreover, turbulence in oil prices reduces the marginal effect of a given oil price change (see Hamilton, 1996; Lee et al., 1995). Thus, asymmetric effects are likely to be weaker or not significant when oil price volatility is accounted for.

\footnotetext{
${ }^{1}$ Hamilton (1996, p. 216) comments that if that is indeed the mechanism by which oil shocks affect the economy, then a decrease in oil prices would not confer a positive effect on the economy that mirrors the negative consequences of an oil price increase.
} 
Our paper addresses this question by analyzing whether oil price volatility has an impact on stock markets, and whether asymmetric effects persist when we account for oil price volatility. Moreover, unlike the previous literature, we distinguish between oil-exporting and oil-importing countries in order to understand whether the transmission effect of oil price changes is different for the stock markets of these two groups. If indeed stock markets mirror the behavior of aggregate output, and if higher oil prices generate additional income to the economy of oil producer countries, then higher oil prices would be expected to foster higher levels of economic activity (Bjørnland, 2000, 2009) and stock markets should anticipate that.

Our study makes a number of contributions. We find that the impact of oil price changes on stock markets runs in different directions for these two groups of countries. Increases in oil prices have a negative impact on the stock market returns of oil-importing countries, while for oil-exporting countries the impact is positive. Oil price drops negatively affect returns of stock market oil-importing countries but have a larger negative impact on the stock markets of oil-exporting countries. The result is consistent with the empirical findings on oil-exporting countries that find that their economies respond positively to oil price changes (Bjørnland, 2000; Jiménez-Rodríguez and Sanchez, 2004). Statistical tests confirm asymmetric effects only for oil-importing countries.

Our results also show that oil price volatility is relevant for stock markets, but again the effects run in different directions for oilimporting and exporting countries. Asymmetric effects do not disappear when we account for volatility, but the coefficient of negative shocks is smaller.

To understand the relationship between oil volatility and oil price variations, we estimate generalized autoregressive conditional heteroscedastic models (GARCH) with exogenous variables related to oil price changes in the conditional variance. The results show that negative oil price changes impact more the conditional variance and consequently oil volatility than positive oil price changes do, also suggesting the existence of asymmetric effects in oil volatility. These results are consistent with the smaller coefficient of negative oil price variations when we account simultaneously for the asymmetric effects of oil and oil volatility.

The structure of the paper is as follows. Section 2 reviews the literature. Section 3 presents the research design and describes the data. Section 4 describes the methodology. Section 5 presents the estimation results of asymmetric effects in oil-importing and oil-exporting countries, including the relation between asymmetric effects and oil price volatility. Section 6 provides a series of robustness tests of the analysis, and Section 7 concludes.

\section{Literature review}

Energy is an important and perversive input for all economic activity. Rises in oil prices increase the costs of running a business, dampen margins, profits, and cash flows (the key drivers of stock prices), and reduce company market value. One might expect that oil price drops have the inverse effect, increasing stock returns, but earlier studies did not find an impact on stock markets (see Chen et al., 1986; Ferson and Harvey, 1994a; Huang et al., 1996). The exception is Jones and Kaul (1996) that find evidence that aggregate stock market returns in the U.S., Canada, Japan, and the U.K. react negatively to the adverse impact of oil price shocks on their economies.

Because stock markets mirror the behavior of aggregate output, some authors have examined whether the oil price asymmetric effects noted in aggregate output (Mork et al., 1994) have parallel in stock market returns, but the evidence is not conclusive. Sadorsky (1999) and Basher and Sadorsky (2006) find evidence of asymmetric oil price effects, whereas Cong et al. (2008), Nandha and Faff (2008), and Park and Ratti (2008) do not.
The effects of oil shocks on the real economy have been differentiated for oil-producing and importing countries. ${ }^{2}$ Both Bjørnland (2000) and Jiménez-Rodríguez and Sanchez (2004) find a different impact for Norway, an oil-exporting country. ${ }^{3}$

But the evidence on the effects of oil price changes on stock markets of oil-exporting stock markets countries is scarce. Park and Ratti (2008) analyze a sample of 14 countries and find that the impact of oil price changes for Norway is different from that of other countries, consistent with the explanations that oil price hikes generate additional income and wealth across oil producers. Bjørnland (2009) analyzes the effects of oil price shocks on Norwegian stock market and advocates that if oil income is transmitted back to an economy, then higher oil prices would be expected to lead to higher levels of economic activity. Consistent with her hypothesis, she found that a $10 \%$ increase in oil prices leads to an increase of $2.5 \%$ in stock returns, which supports the aggregate wealth and demand transmission channel. ${ }^{4}$ A recent paper by Aloui et al. (2012) focuses on the effects of oil price changes in emerging oil-dependent and oil-exporting markets.

The lack of analysis on the role of oil price volatility and asymmetric effects has been a gap in the literature, but there is a strong reason to consider it. Lee et al. (1995) correct oil changes by oil price volatility, arguing that the turbulence in oil prices reduces the marginal effect of any given oil price change. An oil price shock variable reflecting both the unanticipated component and the time-varying conditional variance of oil price change (forecasts) is constructed and found to be highly significant in explaining economic growth across different sample periods, even when matched against various economic variables and other functions of oil price. They find that positive normalized shocks have a powerful effect on growth while negative normalized shocks do not. Ferderer (1996) puts forward an offsetting mechanism based on the interaction of oil price volatility and oil price changes that can create the asymmetric effects found in the literature. He states that the two necessary conditions for explaining the mechanism that creates the asymmetric effects are (1) that oil price changes, whether positive or negative, positively affect oil price volatility, and (2) that oil price volatility (uncertainty) negatively affects the economy. Thus, oil price declines increase oil price volatility, which in turn leads to negative effects on the economy and therefore the positive effects generated by oil price declines are canceled out. Globally, oil price declines have no effect on an economy, while soaring oil prices affect it negatively, and these negative effects are reinforced by the negative effects created by oil price volatility. He tests this hypothesis and finds that when controlling for oil volatility, coefficients of oil price increases and decreases are no longer statistically significant. On the empirical side, studies have tested whether oil price volatility affects stock returns. Among empirical studies, Sadorsky (1999) finds that either an oil price change or its volatility has an impact on real stock returns, Sadorsky (2003) finds an impact of oil volatility on technology stocks and Oberndorfer (2009) on energy stock returns.

\section{Data}

\subsection{Country data}

To investigate the differences in the impact of oil prices in oilimporting and oil-exporting stock markets, we select a set of countries that are heavily dependent on oil imports and a set of countries

\footnotetext{
2 Studies by Mork et al. (1994); Bjørnland (2000); Cuñado and Garcia (2003); Jiménez-Rodríguez and Sanchez (2004) analyze the effect of oil changes on the GDP of oil producing countries.

${ }^{3}$ Jones and Kaul (1996, p. 468) suggest that the effects of oil shocks should vary considerably across different countries depending on their production and consumption of oil reserves.

${ }^{4}$ For a detailed explanation of how an oil shock can affect an oil producing country we refer to Bjørnland (2009).
} 
that are self-sufficient in oil. The first set of countries includes large oil-dependent countries and we label this sample oil-importing countries. The second set of countries includes countries that are self-sufficient in oil, i.e., they consume less than they produce (oil-exporting countries or net oil exporters).

The countries are sorted using country production and consumption data from the International Energy Agency (IEA). Based on the ratio production over consumption, we have separated countries into oil-importing and oil-exporting countries. Since we were analyzing the 1989-2009 period, an additional criterion was that the sufficiency level or dependence did not change in the period, i.e. an oil-importing or a net oil exporter would belong to the same category during the whole time period. These criteria have excluded countries like Brazil from the sample because Brazil has only recently became self-sufficient. ${ }^{5}$

The final sample of stock markets is conditional on the availability of stock market data. This is a problem because many important oil producers do not have well-developed stock markets, including the Persian Gulf countries, among others. ${ }^{6}$

The final sample includes 18 countries. Oil-importing countries are: Austria, Belgium, Finland, France, Germany, Greece, Ireland, Japan, the Netherlands, Portugal, Spain, Sweden, and Switzerland. Oil-exporting countries are Canada, Colombia, Mexico, Norway, and Russia.

We collect monthly returns for country stock market indexes from Datastream, which provides extensive coverage of countries' total market capitalization. Datastream stock market indexes are weighted by market capitalization.

Our sample covers 18 countries from December 1988 through June 2009, for a total of 247 monthly observations. This is an unbalanced panel because data are not available every month for all countries. Returns are computed in U.S. dollars. The choice of U.S. dollars as the reference currency is justified because the price of oil is determined in U.S. dollars in international markets. Stock market returns are the logarithmic changes of excess returns of the local stock market index on a risk free rate (r). Returns are in excess of a short-term interest rate, the one-month Eurodollar interest rate as in Ferson and Harvey (1994a).

All summary statistics and correlations among independent variables are reported in Tables A and B, that can be found in the Appendix.

\subsection{Oil prices}

Oil prices are from the settlement price of the New York mercantile exchange (NYMEX) oil futures contract, the most widely traded futures contract on oil. The underlying asset is West Texas intermediate oil, a light crude oil widely used as a current benchmark for U.S. crude production. Prices are in U.S. dollars per barrel (U\$/BBL). The variable (oil) is the logarithmic difference of oil prices. Summary statistics on the time series are displayed in Table A, Panel B. Oil earned positive mean returns during the period, around $0.6 \%$ monthly, with a standard deviation of almost $10 \%$ monthly.

\subsection{Oil price volatility}

To analyze the effect of oil price volatility we use the estimated volatility from a GARCH $(1,1)$ model $\left(\hat{\sigma}_{\text {garch }}\right)$, as a proxy for oil price volatility, and obtained from

$$
\begin{aligned}
& \text { oil }_{t}=\mu+\sigma_{t} \epsilon_{t} \\
& \sigma_{t}^{2}=\alpha_{0}+\alpha_{1} \varepsilon_{t-1}^{2}+\beta_{1} \sigma_{t-1}^{2},
\end{aligned}
$$

\footnotetext{
${ }^{5}$ Large producers such as the U.S., Australia or the U.K. are not analyzed. As we have noted, the sample of countries needs to be intrinsically different. Even though a country is a producer, the economic effects of oil price rises might be negative because the country still needs to import energy to sustain growth. We defer the analysis of these countries to the robustness section.

${ }^{6}$ Gulf countries have very immature markets with low liquidity.
}

where $\varepsilon_{t}=\sigma_{t} \epsilon_{t}$ is the prediction error, $\sigma_{t}>0$ is the conditional standard deviation of the underlying oil return (denoted volatility) and the innovation $\epsilon_{t} \sim N I D(0,1)$. We impose the conditions $\alpha_{0}>0$, $\alpha_{1} \geq 0$, and $\beta_{1} \geq 0$ to guarantee that the conditional variance is positive and $\alpha_{1}+\beta_{1}<1$ to assure its stationarity.

Oil price volatility is depicted in Fig. 1, and summary statistics in Table A. We can see that oil price volatility has some spikes around 1990, the Gulf War, at the end of the 1990s, and at the end of 2008.

\subsection{Other variables}

According to Stulz (1981) and Adler and Dumas (1983), international excess returns are also explained by the world market portfolio. Datastream provides a world market index, a weighted average of all country index returns. The variable world is the logarithm change of the world stock market portfolio index in excess of a short-term interest rate, the one-month Eurodollar interest rate as in Ferson and Harvey (1994a). This proxy for the market portfolio has been tested empirically in research such as Ferson and Harvey (1994b), Basher and Sadorsky (2006), and Nandha and Faff (2008).

Adler and Dumas (1983) also present theoretical support for the pricing of exchange rate fluctuations in a global setting. Solnik (1974) model advocates that exchange rate risk should be priced in the absence of purchasing power parity. Therefore, we test whether a country index is sensitive to currency rate changes, that is whether the excess return of the stock market of country $i$ shows some sensitivity to changes in currency rates against the U.S. dollar. Dumas and Solnik (1995) and De Santis and Gerard (1998) find that currency risk is conditionally priced for aggregate market returns.

Currency is the logarithmic changes in currency rates against the U.S. dollar. As all bilateral rates are expressed in U.S. dollars by unit of the foreign currency, a positive change in the rate means that the foreign currency has appreciated in relation to U.S. dollars.

\section{Methodology and estimation}

To test for asymmetric effects of oil price variations, we define non-linear measures of oil price changes. The traditional approach is based on a dummy variable that differentiates positive from negative oil price changes and multiplies the variable oil price changes, which is equivalent to the variables:

oilp $_{t}=\max \left(0\right.$, oil $\left._{t}\right)$

oiln $_{t}=\min \left(0\right.$, oil $\left._{t}\right)$.

At time $t$, the variable oilp (oiln) assumes positive (negative) values when changes are positive (negative) and zero otherwise.

Fig. 2 depicts oilp and oiln. Large monthly variations are as great as $+/-20 \%$. There are four steep declines in prices, corresponding to December 1990 and January 1991, the end of the Gulf War; December 2000; March, 2003; and more recently October and December 2008. Price spikes can be seen in July, August, and September 1990, the beginning of the Gulf War; March 1999; May 2000; March 2002; January 2005; and May 2009.

Following Nandha and Faff (2008) and Ramos and Veiga (2011), we use the following specification to test for asymmetry:

$$
\begin{aligned}
r_{i, t}= & \alpha_{i}+\beta_{\text {world }} \cdot \text { world }_{t}+\beta_{\text {curr }} \cdot \text { currency }_{i, t}+\beta_{\text {oilp }} \cdot \text { oilp }_{t}+\beta_{\text {oiln }} \cdot \text { oiln }_{t} \\
& +\beta_{\text {oilp }}^{\prime} \cdot \text { oilp }_{t} \cdot \text { export }^{\prime} \beta_{\text {oiln }}^{\prime} \cdot \text { oiln }_{t} \cdot \operatorname{export}+u_{i, t},
\end{aligned}
$$

where the dependent variable is the excess returns of the stock market of country $i$ at time $t\left(r_{i, t}\right)$. The independent variables are the world stock market's excess return on a risk-free rate at time $t\left(\right.$ world $\left._{t}\right)$; the currency rate changes of country $i$ at time $t$ (currency $\left.y_{i, t}\right)$; and oilp and oiln are variables indicating positive and negative changes in oil prices. $\alpha_{i}$, the intercept, accounts for possible heterogeneity among countries and is 


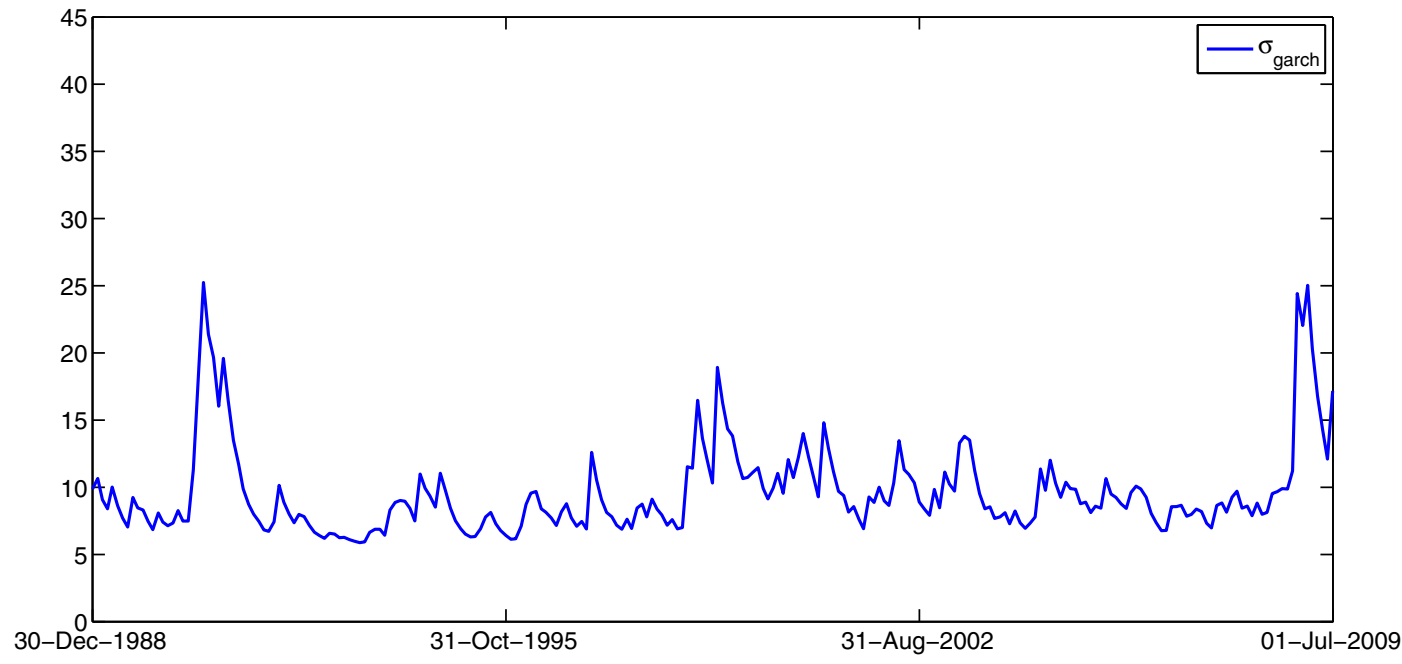

Fig. 1. Oil price volatility obtained using a GARCH(1,1) model.

constant over time. This means that the effect of a change in one explanatory variable is the same for all countries and all periods, but the average level for country $i$ maybe different from that of country $j . u_{i, t}$ is the error of country $i$ at time $t$ and represents the non-systematic excess returns relative to the factors.

To investigate the difference between oil-importing and oil-exporting countries, we define a dummy variable export that interacts with oilp and oiln. This dummy variable is one if the country is an oil-exporting country and zero otherwise. If oil-exporting countries have a different sensitivity to oil price changes, we expect the interaction coefficient to be statistically significant.
We use the same tests of asymmetry used by previous authors (see Nandha and Faff, 2008, for instance). In general terms, asymmetry is defined as the rejection of the null hypothesis of equality of the coefficients of oil positive and negative variations, $H_{01}: \beta_{\text {oilp }}=\beta_{\text {oiln }}$ (Test 1 ). Thus, as long as the coefficients are statistically different, there is rejection of the null. Notice that the null is not rejected if the two variables are not significant. That is, even if oil has a nonsignificant effect on stock markets we could conclude that there are asymmetric effects. To account for this issue, a second null hypothesis is formulated; in this case, both variables must statistically be significantly different from zero, $H_{02}: \beta_{\text {oilp }}=0$ and $\beta_{\text {oiln }}=0$ (Test 2).
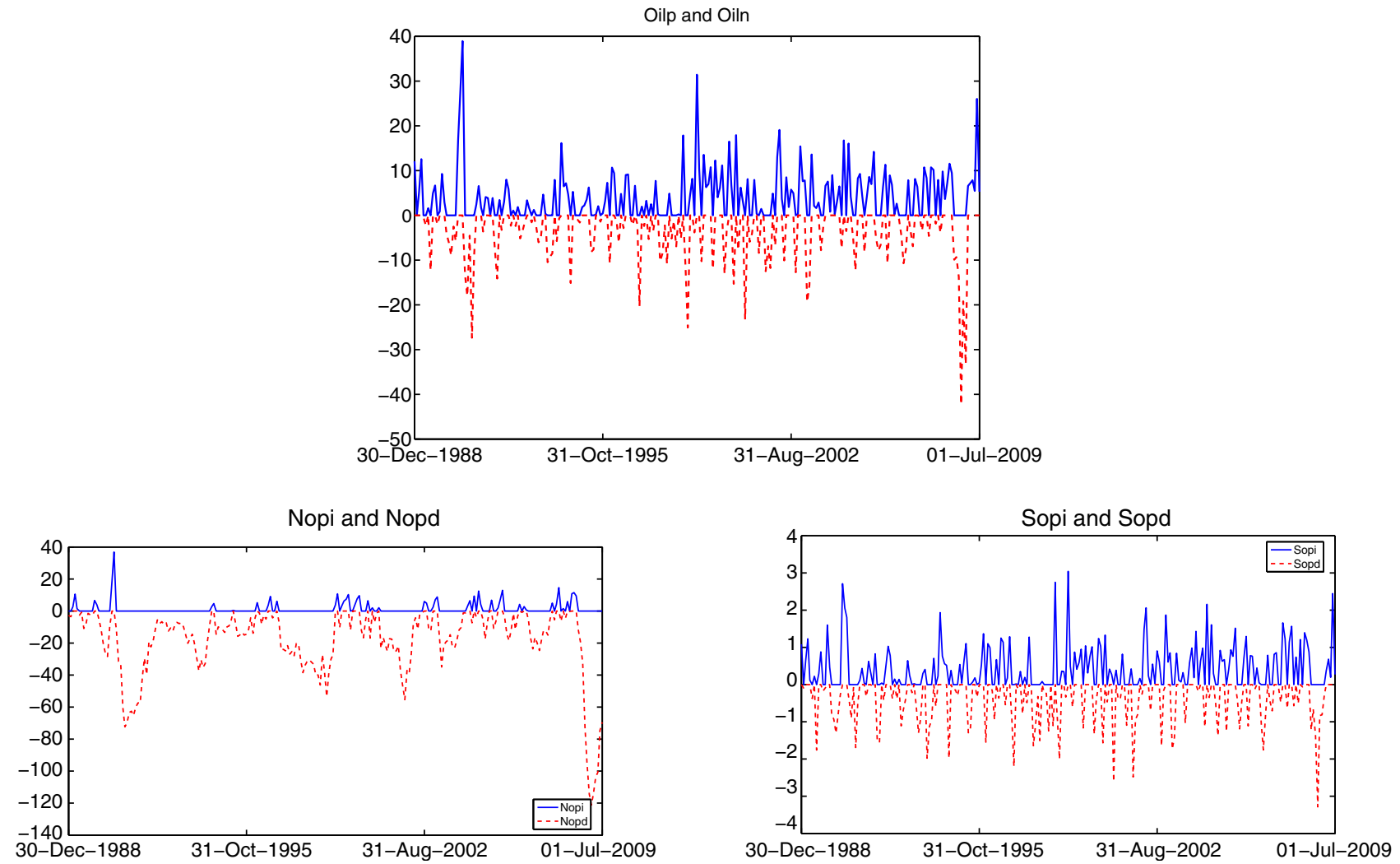

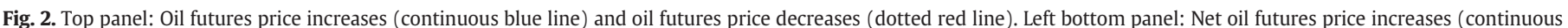

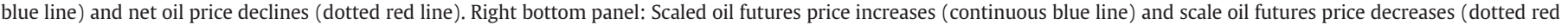
line). 
Asymmetry is therefore confirmed by the rejection of the two null hypotheses: $\mathrm{H}_{01}$ and $\mathrm{H}_{02}{ }^{7}$

Two other measures are introduced in order to capture the effects of oil price shocks or innovations. The first is proposed by Hamilton (1996). He argues that it is more appropriate to compare the current price of oil with its value over the last year rather than during the previous month alone to measure how unsettling an increase in the price of oil is likely to be for the spending decisions of consumers and firms. Net oil price increase (nopi) at time $t$ is defined as:

$\operatorname{nopi}_{t}=\max \left(0, \ln \left(p_{-} o i l_{t}\right)-\ln \left[\max \left(p_{-} o i l_{t-1}, \ldots, p_{-} o i l_{t-12}\right)\right]\right)$.

where nopi can be interpreted as the amount by which the logarithm of oil futures price exceeds its maximum value over the last year (here, $p_{-}$oil $l_{t}$ is used for oil futures price). Note that nopi would be small in a period of consistent oil price escalation, but it is high if prices rise sharply. An advantage of nopi is that it is a better measure for identifying the exogenous component of oil price fluctuations (see Kilian, 2008). Similarly, we define net oil price decline (nopd) at time $t$ as $\operatorname{nopd}_{t}=\min \left(0, \ln \left(p_{-} \text {oil }\right)_{t}-\ln \left[\max \left(p_{-}\right.\right.\right.$oil $_{t-1}, \ldots, p_{-}$oil $\left.\left.\left.t_{-12}\right)\right]\right)$.

nopd is negative when oil prices are below their peak values over the last year. ${ }^{8}$

A similar approach is used to test asymmetry and differences between oil-exporting and oil-importing countries:

$$
\begin{aligned}
r_{i, t}= & \alpha_{i}+\beta_{\text {world }} \cdot \text { world }_{t}+\beta_{\text {curr }} \cdot \text { currency }_{i, t}+\beta_{\text {nopi }} \cdot \text { nopi }_{t}+\beta_{\text {nopd }} \cdot \text { nopd }_{t} \\
& +\beta_{\text {nopi }}^{\prime} \cdot \text { nopi }_{t} \cdot \text { 'export }+\beta_{\text {nopd }}^{\prime} \cdot \text { nopd }_{t} \cdot \text { export }+u_{i, t} \cdot
\end{aligned}
$$

We also explore asymmetry using a measure developed by Lee et al. (1995), called scaled oil price increase (sopi). According to these authors, what matters is how surprising an oil price increase is given already observed changes. An unexpected oil price change will have less of an impact when conditional variances are high because much of the change in oil price will be regarded as transitory.

To calculate this measure we fit a Generalized Autoregressive Conditional Heteroskedasticity Model $(\operatorname{GARCH}(1,1))$ model to oil futures returns. A measure that reflects the size and the variability of an unexpected oil shock might be defined as $\hat{\varepsilon}_{t}^{*}=\frac{\hat{\varepsilon}_{t}}{\hat{\sigma}_{t}}$ so sopi at time $t$ is given by:

$\operatorname{sopi}_{t}=\max \left(0, \hat{\varepsilon}_{t}^{*}\right)$.

Scaled oil price decline (sopd) at time $t$ is defined similarly as $\operatorname{sopd}_{t}=\min \left(0, \hat{\varepsilon}_{t}^{*}\right)$. Therefore, oil price increases and declines are scaled by the conditional standard deviation of oil return. sopi and sopd will be high (in absolute value) when the oil price change is great (in absolute value).

In a similar way, a regression specification also tests non-linear effects of oil prices:

$$
\begin{aligned}
r_{i, t}= & \alpha_{i}+\beta_{\text {world }} \cdot \text { world }_{t}+\beta_{\text {curr }} \cdot \text { currency }_{i, t}+\beta_{\text {sopi }} \cdot \text { sopi }_{t}+\beta_{\text {sopd }} \cdot \text { sopd }_{t}+ \\
& +\beta_{\text {sopi }}^{\prime} \cdot \text { sopi }_{t} \cdot \operatorname{export}+\beta_{\text {sopd }}^{\prime} \cdot \operatorname{sopd}_{t} \cdot \operatorname{export}+u_{i, t},
\end{aligned}
$$

where sopi and sopd capture the asymmetric effects. We also use the interaction with the dummy variable (export) to account for differences between oil-importing countries and oil-exporting countries.

Both nopi (nopd) and sopi (sopd) are non-linear and time-dependent measures. The time dependence of nopi comes from the fact that if a

\footnotetext{
${ }^{7}$ Given model (1), these are the null hypotheses of the asymmetry in oil-importing stock markets. Analogously, the asymmetry test for oil-exporting countries is based on the following null hypotheses: $H_{01}: \beta_{\text {oilp }}+\beta_{\text {oilp }}^{\prime}=\beta_{\text {oiln }}+\beta_{\text {oiln }}^{\prime}$ (Test 1$) ; H_{02}: \beta_{\text {oilp }}+\beta_{\text {oilp }}^{\prime}=0$ and $\beta_{\text {oiln }}+\beta_{\text {oiln }}^{\prime}=0$ (Test 2 ).

8 These measures are frequently used to measure the impact of oil on macroeconomic variables and more recently stock market indexes (see, e.g., Aloui and Jammazi, 2009; Bjørnland, 2009; Cologni and Manera, 2008; Cong et al., 2008; Cuñado and Garcia, 2003; Park and Ratti, 2008; Ramos and Veiga, 2011).
}

shock is not great enough to increase prices above the value in the previous year, then the shock is scaled down to zero. sopi scales down the shocks that occur in a high volatility period and scales up the shocks that occur in a low volatility period.

Fig. 2 plots nopi and nopd for the sample period December 30, 1988-June 30, 2009. We see episodes of peaking prices that seem to cluster in some periods. The nopd also have some peaks and slumps, and we can see a dramatic fall in oil futures prices during 2009.

Fig. 2 also graphs sopi and sopd. Both have some similarities with the respective oil price changes, but they are in a lower scale, due to the standardization.

In models (1) and (2), we will also include oil price volatility ( $\left.\hat{\sigma}_{\text {garch }}\right)$ as an explanatory variable as our aim is to study the asymmetric effects of oil price changes in both oil-importing and oil-exporting country stock markets, when we account for oil volatility. As sopi also accounts for oil price volatility by scaling up and down the shocks depending on the volatility of the period, we do not include oil price volatility in model (3).

Given the structure of the data, we estimate Eqs. (1)-(3) using panel data techniques. Some advantages of this approach are that it enhances both quality and quantity of data, allows more accurate model inference, to control the impact of omitted variables and to study the dynamics of the variable of interest with a relatively short time series. Moreover, intercepts can differ according to country for capturing cross-sectional heterogeneity.

We test fixed and random effects. Although results are quite similar, the Hausman test indicates that the fixed effects specification is often more appropriate. Therefore, hereafter we present estimation results for the fixed effects models where errors are clustered by country and the standard deviations are robust to heteroscedasticity.

Finally, to analyze the relation between oil volatility and price changes we estimate two GARCH models with exogenous variables in the conditional variances:

$o i l_{t}=\mu^{\prime}+\phi^{\prime}$ oil $_{t-1}+\sigma_{t}^{\prime} \epsilon_{t}, \sigma_{t}^{2^{\prime}}=\alpha_{0}^{\prime}+\alpha_{1}^{\prime} \varepsilon_{t-1}^{2^{\prime}}+\beta_{1}^{\prime} \sigma_{t-1}^{2^{\prime}}+\delta_{p} o i l p_{t}$

and

$\mathrm{oil}_{t}=\mu^{\prime \prime}+\phi^{\prime \prime} \mathrm{oil}_{t-1}+\sigma^{\prime \prime}{ }_{t} \epsilon_{t}, \sigma_{t}^{2^{\prime \prime}}=\alpha_{0}^{\prime \prime}+\alpha^{\prime \prime}{ }_{1} \varepsilon_{t-1}^{2^{\prime \prime}}+\beta_{1}^{\prime \prime} \sigma_{t-1}^{2^{\prime \prime}}+\delta_{n} \operatorname{oiln}_{t},(5)$

where $\varepsilon_{t}^{2^{\prime}}=\sigma_{t}^{\prime} \epsilon_{t}, \varepsilon_{t}^{2^{\prime \prime}}=\sigma^{\prime \prime}{ }_{t} \epsilon_{t},\left|\phi^{\prime}\right|<1$ and $\left|\phi^{\prime \prime}\right|<1$ since oil returns are stationary, $\sigma_{t}^{\prime}>0$ and $\sigma_{t}^{\prime \prime}>0$ are the volatilities that might be affected by positive oil price variations and negative oil price variations, respectively, and the innovation $\epsilon_{t} \sim N I D(0,1)$. As for the $\operatorname{GARCH}(1,1)$ model used to estimate the volatility in Section 3, conditions on the parameters are imposed to guarantee the positiveness and the stationarity of the conditional variance.

\section{Empirical results}

We analyze first whether oil price changes create asymmetric effects and whether they are different for oil-importing and oil-exporting countries by estimating Eqs. (1), (2), and (3). Second, we analyze whether oil asymmetry impacts changes in oil price volatility by including this variable in the model. Third, we analyze the relationship between volatility and oil price changes.

\subsection{Asymmetric effects of oil price changes in stock markets}

Table 1 shows the estimation results of Eqs. (1), (2), and (3). Variables world and currency are statistically significant. The coefficient of the variable world is close to one. Therefore the International Capital Asset Pricing Model cannot be rejected. Second, the variable currency is statistically significant and has a positive coefficient similar to that in Carrieri and Majerbi (2006). This means that appreciations of the 
Table 1

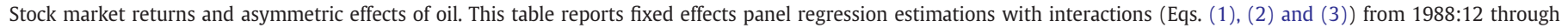

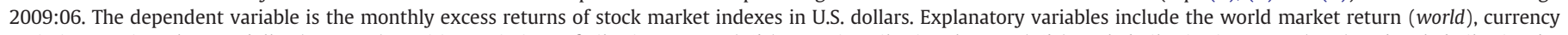

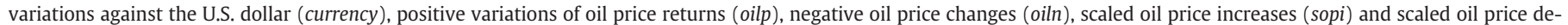

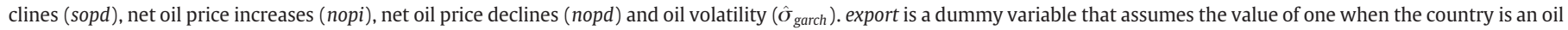

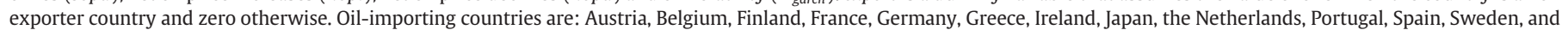

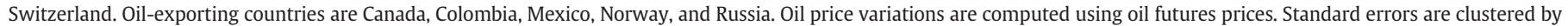
country and are robust to heteroscedasticity. P_values are reported below coefficients.

\begin{tabular}{|c|c|c|c|c|c|c|c|c|}
\hline & (1) & $(2)$ & (3) & & (4) & (5) & & (6) \\
\hline world & $\begin{array}{c}0.922 \\
(0.000)\end{array}$ & $\begin{array}{c}0.933 \\
(0.000)\end{array}$ & $\begin{array}{c}0.923 \\
(0.000)\end{array}$ & world & $\begin{array}{c}0.925 \\
(0.000)\end{array}$ & $\begin{array}{c}0.926 \\
(0.000)\end{array}$ & world & $\begin{array}{c}0.927 \\
(0.000)\end{array}$ \\
\hline currency & $\begin{array}{c}0.560 \\
(0.000)\end{array}$ & $\begin{array}{c}0.546 \\
(0.000)\end{array}$ & $\begin{array}{c}0.558 \\
(0.000)\end{array}$ & currency & $\begin{array}{c}0.551 \\
(0.000)\end{array}$ & $\begin{array}{c}0.550 \\
(0.000)\end{array}$ & currency & $\begin{array}{c}0.560 \\
(0.000)\end{array}$ \\
\hline oilp & $\begin{array}{r}-0.107 \\
(0.000)\end{array}$ & & $\begin{array}{r}-0.100 \\
(0.000)\end{array}$ & nopi & $\begin{array}{r}-0.111 \\
(0.000)\end{array}$ & $\begin{array}{r}-0.095 \\
(0.002)\end{array}$ & sopi & $\begin{array}{r}-0.895 \\
(0.000)\end{array}$ \\
\hline oiln & $\begin{array}{c}0.048 \\
(0.021)\end{array}$ & & $\begin{array}{r}0.0400 \\
(0.075)\end{array}$ & nopd & $\begin{array}{c}0.007 \\
(0.054)\end{array}$ & $\begin{array}{c}0.001 \\
(0.815)\end{array}$ & sopd & $\begin{array}{c}0.302 \\
(0.091)\end{array}$ \\
\hline oilp $\cdot$ export & $\begin{array}{c}0.189 \\
(0.000)\end{array}$ & & $\begin{array}{c}0.171 \\
(0.000)\end{array}$ & nopi $\cdot$ export & $\begin{array}{c}0.211 \\
(0.001)\end{array}$ & $\begin{array}{c}0.172 \\
(0.011)\end{array}$ & sopi $\cdot$ export & $\begin{array}{c}1.673 \\
(0.000)\end{array}$ \\
\hline oiln $\cdot$ export & $\begin{array}{c}0.069 \\
(0.245)\end{array}$ & & $\begin{array}{c}0.09 \\
(0.131)\end{array}$ & nopd $\cdot$ export & $\begin{array}{c}0.000 \\
(0.990)\end{array}$ & $\begin{array}{c}0.014 \\
(0.109)\end{array}$ & sopd $\cdot$ export & $\begin{array}{c}0.675 \\
(0.231)\end{array}$ \\
\hline$\hat{\sigma}_{\text {garch }}$ & & $\begin{array}{c}-0.081 \\
(0.006)\end{array}$ & $\begin{array}{c}-0.042 \\
(0.179)\end{array}$ & $\hat{\sigma}_{\text {garch }}$ & & $\begin{array}{c}-0.065 \\
(0.112)\end{array}$ & & \\
\hline$\hat{\sigma}_{\text {garch }} \cdot$ export & & $\begin{array}{c}0.130 \\
(0.034)\end{array}$ & $\begin{array}{c}0.128 \\
(0.042)\end{array}$ & $\hat{\sigma}_{\text {garch }} \cdot$ export & & $\begin{array}{c}0.161 \\
(0.036)\end{array}$ & & \\
\hline Constant & $\begin{array}{c}0.721 \\
(0.000)\end{array}$ & $\begin{array}{c}0.725 \\
(0.006)\end{array}$ & $\begin{array}{c}0.81 \\
(0.002)\end{array}$ & Constant & $\begin{array}{c}0.460 \\
(0.000)\end{array}$ & $\begin{array}{c}0.655 \\
(0.018)\end{array}$ & Constant & $\begin{array}{c}0.636 \\
(0.000)\end{array}$ \\
\hline Observations & 4238 & 4238 & 4238 & & 4238 & 4238 & & 4238 \\
\hline Countries & 18 & 18 & 18 & & 18 & 18 & & 18 \\
\hline$R^{2}$ & 0.514 & 0.503 & 0.514 & & 0.507 & 0.508 & & 0.511 \\
\hline \multicolumn{9}{|c|}{ Oil-importing countries } \\
\hline $\begin{array}{l}\text { Test } 1 \\
P \text { value }\end{array}$ & 26.600 & & 16.980 & & $\begin{array}{l}25.260 \\
(0.000)\end{array}$ & $\begin{array}{l}10.990 \\
(0.004)\end{array}$ & & $\begin{array}{c}23.640 \\
(0.000)\end{array}$ \\
\hline $\begin{array}{l}\text { P_value } \\
\text { Test } 2\end{array}$ & 20.250 & & 16.350 & & 12.680 & $\begin{array}{c}(0.004) \\
9.650\end{array}$ & & $\begin{array}{l}(0.000) \\
18.300\end{array}$ \\
\hline P_value & $(0.000)$ & & $(0.000)$ & & $(0.000)$ & $(0.002)$ & & $(0.000)$ \\
\hline \multicolumn{9}{|c|}{ Oil-exporting countries } \\
\hline Test 1 & 1.740 & & 3.440 & & 4.430 & 1.150 & & 0.300 \\
\hline P_value & $(0.205)$ & & $(0.081)$ & & $(0.050)$ & $(0.299)$ & & $(0.590)$ \\
\hline Test 2 & 3.490 & & 3.330 & & 2.330 & 3.440 & & 8.790 \\
\hline P_value & $(0.054)$ & & $(0.060)$ & & $(0.128)$ & $(0.056)$ & & $(0.002)$ \\
\hline
\end{tabular}

local currency against the U.S. dollar have a positive effect on stock market returns.

Results are consistent with a conjecture of non-linear effects for oil-importing countries. Column (1) shows the impact of positive and negative changes of oil returns. The coefficient of $\beta_{\text {oilp }}$ is negative, and the coefficient of $\beta_{\text {oiln }}$ is positive, and both variables are statistically significant. The sign of the coefficients suggests that when oil prices soar, stock market returns drop, but when oil prices fall, stock markets do not climb; but stock returns are again likely to drop. Note also that the positive variations are greater than negative variations.

Interaction variables are also statistically significant. oilp for oilexporting countries is statistically significant, and its coefficient is positive $(-0.107+0.189)$. The shift of sign in the coefficient of oilp for oil-exporting countries is consistent with the idea that oil revenues have a positive impact on these economies. On the other hand, the coefficient of oiln is also positive $(0.048+0.069)$ and statistically significant. The signs of oilp and oiln indicate that stock market returns follow oil price changes. Finally, we note that the coefficient is higher for oil price falls in oil-exporting countries.

The last rows in Table 1 present the results of the asymmetry tests for oil-importing and exporting countries. They show that oil asymmetric effects are confirmed statistically only for oil-importing countries through the rejection of the nulls of Test 1 and Test 2.

Column (4) uses nopi and nopd to measure asymmetric effects. nopi has a negative coefficient for oil-importing countries. For oil-exporting countries, the coefficient is positive $(-0.111+0.211)$ but the variable is statistically significant at weaker levels. nopd is statistically significant at weaker levels only for oil-importing countries, and it is not statistically significant for oil-exporting countries. Once again oil price hikes have a greater impact than oil price drops.

We next control for oil price volatility in two ways. First, we introduce oil price volatility in Eqs. (1) and (2). Second, we use a measure of asymmetry that already accounts for oil price volatility (see Eq. (3)). The first approach gives us the partial effects of the explanatory variables or their ceteris paribus interpretations, and the second approach is time-varying and proposes two variables that are scaled up or down according to oil price volatility.

To begin with, column (2) shows the results for the impact of oil price volatility alone, ignoring asymmetry. Oil price volatility has a negative impact on stock market returns of oil-importing countries, whereas the sign changes for oil-exporting countries, the coefficient becomes positive $(-0.081+0.13)$. The coefficients are both statistically significant at standard levels of significance.

We next include the variables that capture asymmetry. Column (3) shows the results for oilp and oiln and column (5) for nopi and nopd. When we control for oil price volatility, only oilp and nopi are statistically significant for oil-importing countries (at the $5 \%$ confidence level). For oil-exporting countries, the impact of oil price rises is reversed and statistically significant. The oilp coefficient is $(-0.100+0.171)$, and the nopi coefficient is $(-0.095+0.172)$.

Oil price volatility has a negative effect on the stock market returns of oil-importing countries but it is not statistically significant. The reversal of sign for oil-exporting countries is statistically significant, highlighting the difference in impact. Thus, asymmetric effects 
seem to have a greater impact than oil price volatility and the fact that oil price volatility becomes less significant makes us think that oil non-linear effects might account for oil price volatility.

Statistical tests confirm asymmetric effects of oil for oil-importing countries using both measures of asymmetry, while for oil-exporting countries, they are confirmed at a weaker level of significance using oilp and oiln. Overall, the results only reinforce the importance of oil's non-linear effects in international stock markets.

Column (6) uses sopi and sopd to measure the non-linear effects. Only sopi is statistically significant at standard levels of confidence for oil-importing countries and has a negative coefficient. sopd is statistically significant only at weaker levels of significance. For oil-exporting countries, price rises have a statistically significant positive effect $(-0.895+1.673)$, but price declines are statistically significant at weaker levels of confidence. Therefore, when we account for instability in prices, price hikes seem to matter more than price drops for stock market returns. Asymmetry tests confirm the asymmetric effects only for oil-importing countries.

Overall, oil price changes have an impact on the stock market returns of oil-importing and oil-exporting countries, but the asymmetry tests support oil asymmetric effects only in the stock markets of oil-importing countries. Oil price volatility effects are also different for oil-importing and oil-exporting countries, ${ }^{9}$ but lose importance when we include asymmetry measures. This is line with the effects of negative changes in oil prices being canceled out as discussed by Ferderer (1996).

\subsection{Relationship between oil price changes and oil price volatility}

So far we have documented that oil price changes have non-linear effects on international stock market returns. An important related issue is whether positive and negative oil price changes affect oil price volatility. In order to answer this question we estimate two GARCH models with exogenous variables in the conditional variances, see Eqs. (4) and (5).

The results are reported in Table 2 . We observe that both the positive and negative oil price variations positively affect the conditional variance and consequently the estimates of volatility. Moreover, since the absolute value of the coefficients associated to oil price variations is large for negative variations, it suggests that negative oil price variations impact the volatility estimates more than positive oil price variations. We also calculate the correlations between negative price changes and oil volatility measures (see Table I of the supplementary appendix); looking at the table, we observe that oiln is more correlated with the volatility estimates than oilp (in absolute value), suggesting a strong relationship between oil price drops and oil volatility for the majority of the oil volatility measures.

\section{Robustness analysis}

In this section we examine whether the results persist using other specifications.

First, we investigate whether using alternatives measures of oil price volatility makes a difference to our results. The first volatility measure is proposed by Oberndorfer (2009) ( $\hat{\sigma}_{\text {oberndorfer }}$ ) to deal with the volatility estimation problem of errors-in-variables that can occur when the market works efficiently and we use

\footnotetext{
${ }^{9}$ Real options theory offers a possible explanation for the positive effect of oil volatility in market returns of oil-exporting countries. In this framework, oil producers are characterized as call options, and it is well know that option value increases with volatility. Litzenberger and Rabinowitz (1995) refer "as uncertainty about the futures price oil increase, the value of oil reserves, like the value of a call option, increases" (pag. 1531) If income is transmitted back to an economy, then it is expected to lead to higher levels of economic activity, which can be anticipated in stock markets (Bjørnland, 2009).
}

Table 2

Relation between oil price volatility and oil price variations. This table reports the estimations of GARCH models with exogenous variables (Eqs. (4) and (5)). The sample period runs from 1988:12 through 2009:06. n.s. means that it was not significant in a previous estimation and it was posteriorly removed in the final estimation of the model. In parenthesis, we report the P_values of the significance tests.

\begin{tabular}{llc}
\hline & $(1)$ & $(2)$ \\
\hline$\mu$ & -1.508 & 3.140 \\
$\operatorname{ar}(1)$ & $(0.076)$ & $(0.000)$ \\
$\alpha_{0}^{\prime}$ & 0.180 & \\
& $(0.019)$ & \\
$\alpha_{0}^{\prime}{ }^{\prime}$ & 0.120 & 2.466 \\
$\delta_{p}$ & $(0.954)$ & $(0.456)$ \\
$\delta_{n}$ & & \\
$\alpha_{1}^{\prime}$ & 4.315 & -8.750 \\
$\alpha_{1}^{\prime}$ & $(0.000)$ & $(0.000)$ \\
$\beta_{1}^{\prime}$ & & \\
$\beta^{\prime \prime}$ & $n . s$. & 0.145 \\
& & $(0.093)$ \\
\hline
\end{tabular}

estimates of volatility based on innovations coming from fitting GARCH-type models. $\hat{\sigma}_{\text {oberndorfer }}$ is based on the estimation of an AR(K) model:

$w_{t}=\theta_{j}+\sum_{k=1}^{K} \alpha_{k} w_{t-k}+s_{t}$,

where $w_{t}$ is the squared oil price change at the end of the period $t$ and $s_{t}$ is simultaneously the perturbation that has mean zero and variance $\omega^{2}$ and the volatility innovation at time t. $\alpha_{k}$ is the coefficient of the lagged $k$ squared oil price change. The model is estimated using Ordinary Least Squares (OLS) and the lag length is determined by the usual significance tests and the Bayesian Schwarz Information Criterion (BIC). The lag length $K$ is three.

The second, provided by Schwert (1989) $\left(\hat{\sigma}_{\text {schwert }}\right)$ relies on the absolute value of the residuals obtained by fitting an autoregressive model to oil futures returns, that is:

$\mathrm{oil}_{t}=\alpha+\sum_{i=1}^{L} \phi_{i} o i l_{t-i}+u_{t}$

where $u_{t}$ follows a normal distribution with mean zero and variance $\psi^{2}$. $\phi_{i}$ is the coefficient of the lagged $i$ oil price change. The model is estimated by OLS and the regression lag length $(L)$ is determined by the usual significance tests and the BIC. In our case $L=1$. The volatility is then the absolute value of the regression residuals, $\hat{u}_{t}$, which corresponds to an estimate of the conditional variance of oil futures returns.

The third measure is also obtained by estimating an autoregressive model, but we apply a moving average of order $m+1$ to the squared residuals obtained by fitting the previous model to oil futures returns:

$\hat{\sigma}_{\text {gallant }_{t}}=\left[(m+1)^{-1} \sum_{j=0}^{m} \hat{\epsilon}_{t-j}^{2}\right]^{0.5}$.

Instead of considering a single residual in the calculation of volatility, with this method we weight the neighbor residuals (see Gallant and Tauchen, 1998). As in Gallant and Tauchen (1998), we use $m+4$. Table 3 shows that the main results are robust to the alternative specifications. 
Table 3

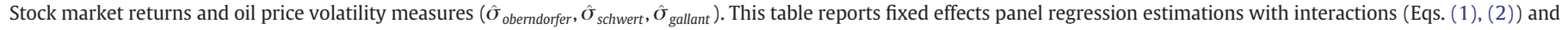

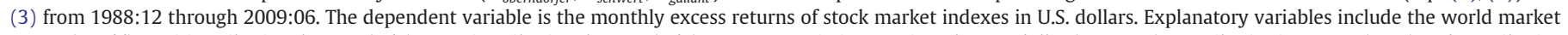

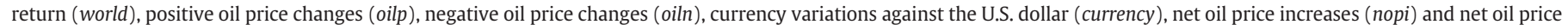

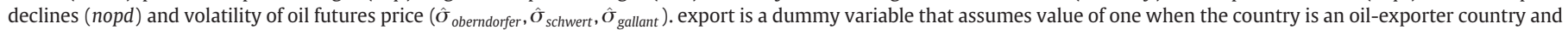

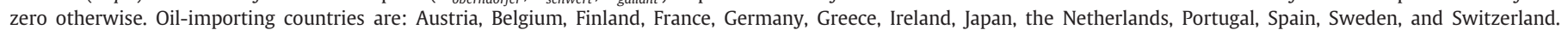

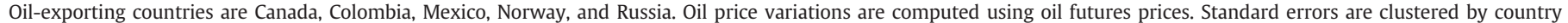
and are robust to heteroscedasticity. P_values are reported below coefficients.

\begin{tabular}{|c|c|c|c|c|c|c|}
\hline & $(1)$ & $(2)$ & (3) & $(4)$ & (5) & (6) \\
\hline world & $\begin{array}{c}0.911 \\
(0.000)\end{array}$ & $\begin{array}{c}0.922 \\
(0.000)\end{array}$ & $\begin{array}{c}0.922 \\
(0.000)\end{array}$ & $\begin{array}{c}0.911 \\
(0.000)\end{array}$ & $\begin{array}{c}0.922 \\
(0.000)\end{array}$ & $\begin{array}{c}0.922 \\
(0.000)\end{array}$ \\
\hline currency & $\begin{array}{c}0.561 \\
(0.000)\end{array}$ & $\begin{array}{c}0.561 \\
(0.000)\end{array}$ & $\begin{array}{c}0.567 \\
(0.000)\end{array}$ & $\begin{array}{c}0.563 \\
(0.000)\end{array}$ & $\begin{array}{c}0.562 \\
(0.000)\end{array}$ & $\begin{array}{c}0.559 \\
(0.000)\end{array}$ \\
\hline oilp & $\begin{array}{r}-0.073 \\
(0.020)\end{array}$ & $\begin{array}{r}-0.079 \\
(0.167)\end{array}$ & $\begin{array}{r}-0.106 \\
(0.000)\end{array}$ & & & \\
\hline oiln & $\begin{array}{c}0.014 \\
(0.557)\end{array}$ & $\begin{array}{c}0.016 \\
(0.794)\end{array}$ & $\begin{array}{c}0.040 \\
(0.099)\end{array}$ & & & \\
\hline oilp $\cdot$ export & $\begin{array}{c}0.282 \\
(0.001)\end{array}$ & $\begin{array}{c}0.150 \\
(0.055)\end{array}$ & $\begin{array}{c}0.179 \\
(0.000)\end{array}$ & & & \\
\hline oilp $\cdot$ export & $\begin{array}{r}-0.024 \\
(0.726)\end{array}$ & $\begin{array}{c}0.115 \\
(0.349)\end{array}$ & $\begin{array}{c}0.088 \\
(0.183)\end{array}$ & & & \\
\hline$\hat{\sigma}_{\text {oberndorfer }}$ & $\begin{array}{r}-0.001 \\
(0.282)\end{array}$ & & & $\begin{array}{r}-0.002 \\
(0.010)\end{array}$ & & \\
\hline$\hat{\sigma}_{\text {oberndorfer }} \cdot$ export & $\begin{array}{r}-0.004 \\
(0.166)\end{array}$ & & & $\begin{array}{r}-0.001 \\
(0.498)\end{array}$ & & \\
\hline$\hat{\sigma}_{\text {schwert }}$ & & $\begin{array}{r}-0.032 \\
(0.545)\end{array}$ & & & $\begin{array}{r}-0.062 \\
(0.000)\end{array}$ & \\
\hline$\hat{\sigma}_{\text {schwert }}$ export & & $\begin{array}{c}0.047 \\
(0.562)\end{array}$ & & & $\begin{array}{c}0.012 \\
(0.681)\end{array}$ & \\
\hline$\hat{\sigma}_{\text {gallant }}$ & & & $\begin{array}{r}-0.019 \\
(0.421)\end{array}$ & & & $\begin{array}{r}-0.061 \\
(0.020)\end{array}$ \\
\hline$\hat{\sigma}_{\text {gallant }} \cdot$ export & & & $\begin{array}{c}0.060 \\
(0.123)\end{array}$ & & & $\begin{array}{c}0.062 \\
(0.048)\end{array}$ \\
\hline nopi & & & & $\begin{array}{r}-0.069 \\
(0.002)\end{array}$ & $\begin{array}{r}-0.077 \\
(0.001)\end{array}$ & $\begin{array}{r}-0.099 \\
(0.001)\end{array}$ \\
\hline nopd & & & & $\begin{array}{c}0.003 \\
(0.433)\end{array}$ & $\begin{array}{c}0.002 \\
(0.615)\end{array}$ & $\begin{array}{c}0.000 \\
(0.968)\end{array}$ \\
\hline nopi $\cdot$ export & & & & $\begin{array}{r}-0.002 \\
(0.706)\end{array}$ & $\begin{array}{c}0.001 \\
(0.899)\end{array}$ & $\begin{array}{c}0.006 \\
(0.414)\end{array}$ \\
\hline nopd $\cdot$ export & & & & $\begin{array}{c}0.224 \\
(0.002)\end{array}$ & $\begin{array}{c}0.201 \\
(0.004)\end{array}$ & $\begin{array}{c}0.197 \\
(0.002)\end{array}$ \\
\hline Constant & $\begin{array}{c}0.287 \\
(0.087)\end{array}$ & $\begin{array}{c}0.729 \\
(0.000)\end{array}$ & $\begin{array}{c}0.733 \\
(0.000)\end{array}$ & $\begin{array}{c}0.307 \\
(0.000)\end{array}$ & $\begin{array}{c}0.765 \\
(0.000)\end{array}$ & $\begin{array}{c}0.725 \\
(0.000)\end{array}$ \\
\hline Observations & 4210 & 4224 & 4168 & 4210 & 4224 & 4168 \\
\hline$R^{2}$ & 0.517 & 0.514 & 0.517 & 0.512 & 0.51 & 0.512 \\
\hline Countries & 18 & 18 & 18 & 18 & 18 & 18 \\
\hline Oil-importing cou & & & & & & \\
\hline $\begin{array}{l}\text { Test } 1 \\
\text { P_value } \\
\text { Test } 2 \\
\text { P_value }\end{array}$ & $\begin{array}{c}3.23 \\
(0.090) \\
4.99 \\
(0.020)\end{array}$ & $\begin{array}{c}0.69 \\
(0.419) \\
6.89 \\
(0.006)\end{array}$ & $\begin{array}{l}15.44 \\
(0.001) \\
17.9 \\
(0.000)\end{array}$ & $\begin{array}{c}12.66 \\
(0.002) \\
6.69 \\
(0.007)\end{array}$ & $\begin{array}{c}13.68 \\
(0.002) \\
7.71 \\
(0.004)\end{array}$ & $\begin{array}{l}14.62 \\
(0.002) \\
11.35 \\
(0.007)\end{array}$ \\
\hline Oil-exporting cou & & & & & & \\
\hline $\begin{array}{l}\text { Test } 1 \\
\text { P_value } \\
\text { Test } 2 \\
\text { P_value }\end{array}$ & $\begin{array}{c}5.56 \\
(0.031) \\
6.59 \\
(0.008)\end{array}$ & $\begin{array}{c}0.22 \\
(0.649) \\
3.88 \\
(0.042)\end{array}$ & $\begin{array}{c}1.58 \\
(0.225) \\
3.38 \\
(0.058)\end{array}$ & $\begin{array}{c}7.54 \\
(0.014) \\
5.12 \\
(0.018)\end{array}$ & $\begin{array}{c}4.61 \\
(0.046) \\
2.8 \\
(0.089)\end{array}$ & $\begin{array}{c}3.47 \\
(0.080) \\
1.74 \\
(0.205)\end{array}$ \\
\hline
\end{tabular}

We conduct a number of further tests to examine the robustness of our results. ${ }^{10}$

The country selection was based on the level of dependence versus self-sufficiency of oil. Important oil producers whose oil consumption is higher than oil production were excluded from the groups of oil-importing and oil-exporting countries. If indeed the transmission of wealth is the mechanism as argued in Bjørnland (2000) and Bjørnland (2009), it is likely that effects of oil changes in stock markets of these countries might be blurred because of simultaneous opposite effects.

To address this issue, we analyze the impact of oil price changes in a group of oil producers whose production is not enough to cover their needs during the time sample. In alphabetical order they are: Australia,

10 Tables are available in the Supplementary Appendix.
Brazil, Indonesia, New Zealand, South Africa, Romania, Thailand, the U.K. and the U.S. Likewise, we create a dummy (cons_prod) to identify these consumer \& producing countries and make the interaction of the dummy with the nonlinear functions of oil.

The results report a lower level of asymmetric effects for these countries that is not statistically significant, differently from oil-importing countries where tests confirm statistical significance. Moreover, they also differentiate from net oil exporters, because coefficients of oil price increases and oil volatility are positive.

We examine the impact of using a different oil price proxy, the price index of London Brent crude oil. Measures of oil price asymmetry and oil price volatility are recomputed using the London Brent crude oil price in U\$/BBL. Our results remain largely unchanged.

Works by Chen et al. (1986) and Chen (1991) have shown that industrial production has an effect on stock markets. We re-run the main estimations controlling for industrial production. We 
compute annual changes in industrial production following Chen (1991) as

ind_prod $_{t}=\ln \left(I P_{t}\right)-\ln \left(I P_{t-12}\right)$,

where the $I P_{t}$ is the level of seasonally unadjusted industrial production for month $t$. This specification using a 12 month lag corrects for seasonality in the industrial production.

A problem is that not all the countries have monthly industrial data for the time period. Thus the coverage of the countries is unbalanced, both in countries and in time. Our results are almost unchanged. Industrial production is not statistically significant and asymmetry results are kept unchanged for oil-importing countries.

Finally, we address the concern that results could be driven by the weight of the oil and gas sector in the stock markets of the sample of oil-exporting countries. To answer this question, we investigate the nonlinear effects by sector. We use the industrial decomposition of Datastream for ten sectors in Level 2. Sectors are: Basic materials (basicmat), Consumer goods (consgood), Consumer Services (consserv), Financials (financials), Health Care (healthcare), Industrials (industrials), Oil and Gas (oilgas), technology (technology), Telecommunications (telecom), and Utilities (utilities).

We reestimate Eqs. (1), (2), and (3) using the returns of sectors as dependent variables instead of country stock market returns. This allows us to see whether the non-oil related sectors have a different response to oil price changes and whether the asymmetry is driven by the weight of the oil and gas sector in a stock market. The sector results are quite consistent with those of stock markets, suggesting that the asymmetric effects of oil are not driven by the weight of the oil and gas sector in an economy.

\section{Conclusion}

We have documented new results about the influence of oil price fluctuations in international stock markets over the period 19882009. First, oil price changes have non-linear effects that run in different directions for oil-importing and oil-exporting countries. Oil price hikes have a negative impact on the stock markets of oil-importing countries, while for oil-exporting countries the impact is positive. Oil price drops negatively impact the stock markets of oil-importing countries, but the stock market returns of oil-exporting countries fall even more.

Second, when we account for oil price volatility, only oil price hikes are statistically significant. Moreover, the asymmetric effects for oil-importing countries are robust to the inclusion of oil price volatility. Oil price volatility has a negative impact on the stock markets of oil-importing countries and a positive effect on oil-exporting countries, but negative oil price shocks tend to have no effect when we account for oil price volatility. This evidence supports the offsetting mechanism conjectured in Ferderer (1996) that oil price volatility offsets the positive impact of drops in oil prices. First, oil price volatility has a negative effect on the stock market returns of oil-importing countries. Second, oil price drops increase oil price volatility, producing a negative effect on the returns of stock markets of oil-importing countries that offsets the positive effects on the economy generated by oil price declines.

Our results are consistent with published empirical evidence elsewhere that shows that the economies of oil-exporting countries respond positively to oil price shocks (see Bjørnland, 2009; Korhonen and Ledyaeva, 2010; Mork et al., 1994, for evidence for Norway and for Russia and Canada, respectively) and similar to those on the response of oil and gas companies around the world (see Ramos and Veiga, 2011).

Understanding the impact of oil price fluctuations has become an important element in investment decisions and consequently in risk management. Our analysis helps us understand the workings of oil price changes in stock markets. Considerable work remains to be done to validate the theories and the mechanisms that explain the non-linear effects of oil price changes.

\section{Appendix A}

Table A

Summary statistics of variables. This table reports the summary statistics of the variables. Panels A.1 and A.2 report stock market index monthly returns by country. Panel B reports the same statistics for the variables oil futures returns (oil), world market return (world), currency variations against the U.S. dollar (currency), and oil volatility $\left(\hat{\sigma}_{\text {garch }}\right)$. The sample period ranges from 1988:12 to 2009:06. By column, we report the mean, the standard deviation (SD), the kurtosis, the skewness and the Jarque-Bera test statistics. The returns are the first differences of the logarithm of prices in percentage. Superscripts *, ** and *** denote statistical significance at $10 \%, 5 \%$ and $1 \%$ levels respectively. Source: Datastream.

\begin{tabular}{|c|c|c|c|c|c|}
\hline \multirow[b]{2}{*}{ Country } & \multicolumn{5}{|c|}{ Panel A: stock market returns } \\
\hline & Mean & SD & Kurtosis & Skewness & Jarque-Bera \\
\hline \multicolumn{6}{|c|}{ Panel A.1: oil-importing countries } \\
\hline Austria & 0.214 & 7.110 & 11.098 & -1.491 & $750.525^{* * *}$ \\
\hline Belgium & -0.043 & 5.697 & 14.073 & -1.908 & $1384.900^{* * *}$ \\
\hline Finland & 0.135 & 8.778 & 3.968 & -0.247 & $11.491^{* * *}$ \\
\hline France & 0.126 & 5.637 & 4.937 & -0.793 & $62.617^{* * *}$ \\
\hline Germany & 0.093 & 5.985 & 5.204 & -0.876 & $79.335^{* * *}$ \\
\hline Greece & 0.466 & 10.002 & 7.718 & 0.650 & $240.315^{* * *}$ \\
\hline Ireland & 0.046 & 6.363 & 7.865 & -1.064 & $283.564^{* * *}$ \\
\hline Japan & -0.604 & 6.476 & 3.727 & 0.153 & $5.973^{*}$ \\
\hline Netherlands & 0.085 & 5.793 & 14.051 & -2.192 & $1427.300^{* * *}$ \\
\hline Portugal & -0.124 & 6.100 & 6.588 & -0.885 & $150.986^{* * *}$ \\
\hline Spain & 0.111 & 6.230 & 5.095 & -0.675 & $61.966^{* * *}$ \\
\hline Sweden & 0.156 & 7.515 & 4.425 & -0.635 & $36.287^{* * *}$ \\
\hline Switzerland & 0.344 & 4.919 & 4.253 & -0.528 & $26.639^{* * *}$ \\
\hline \multicolumn{6}{|c|}{ Panel A.2: oil-exporting countries } \\
\hline Canada & 0.251 & 5.486 & 8.198 & -1.171 & $326.795^{* * *}$ \\
\hline Colombia & -0.579 & 3.102 & 4.893 & -0.405 & $35.340^{* * *}$ \\
\hline Mexico & 0.685 & 9.287 & 6.781 & -1.239 & $205.320^{* * *}$ \\
\hline Norway & 0.350 & 7.725 & 8.209 & -1.348 & $345.906^{* * *}$ \\
\hline \multirow[t]{3}{*}{ Russia } & 1.381 & 14.522 & 5.674 & -0.966 & $78.672^{* * *}$ \\
\hline & \multicolumn{5}{|c|}{ Panel B: independent variables } \\
\hline & Mean & SD & Kurtosis & Skewness & Jarque-Bera \\
\hline oil & 0.618 & 9.852 & 5.425 & -0.277 & $61.492^{\text {*** }}$ \\
\hline world & -0.052 & 4.639 & 6.026 & -0.965 & $129.149^{* * *}$ \\
\hline $\begin{array}{l}\hat{\sigma}_{\text {garch }} \\
\text { currency }\end{array}$ & 9.597 & 3.309 & 9.413 & 2.307 & $629.856^{\text {*** }}$ \\
\hline Austria & 0.087 & 3.062 & 4.283 & -0.354 & $21.129^{* * *}$ \\
\hline Belgium & 0.094 & 3.046 & 4.319 & -0.386 & $23.035^{* * *}$ \\
\hline Finland & -0.016 & 3.235 & 4.700 & -0.506 & $38.900^{* * *}$ \\
\hline France & 0.095 & 3.021 & 4.311 & -0.365 & $22.169^{* * *}$ \\
\hline Germany & 0.106 & 3.053 & 4.423 & -0.311 & $22.574^{* * *}$ \\
\hline Greece & -0.212 & 3.052 & 4.822 & -0.474 & $41.806^{* * *}$ \\
\hline Ireland & 0.055 & 3.071 & 4.486 & -0.469 & $30.496^{* * *}$ \\
\hline Japan & 0.094 & 3.151 & 5.898 & 0.452 & $91.876^{* * *}$ \\
\hline Netherlands & 0.089 & 3.060 & 4.264 & -0.334 & $20.140^{* * *}$ \\
\hline Portugal & 0.003 & 3.056 & 4.471 & -0.337 & $25.815^{* * *}$ \\
\hline Spain & -0.021 & 3.194 & 4.549 & -0.539 & $35.358^{* * *}$ \\
\hline Sweden & -0.101 & 3.341 & 4.908 & -0.680 & $54.678^{* * *}$ \\
\hline Switzerland & 0.117 & 3.240 & 4.038 & -0.039 & $10.400^{* * *}$ \\
\hline Canada & 0.009 & 2.055 & 9.018 & -0.505 & $373.740^{* * *}$ \\
\hline Colombia & -0.579 & 3.102 & 4.893 & -0.405 & $35.340^{* * *}$ \\
\hline Mexico & -0.705 & 3.813 & 39.825 & -4.568 & $14555.000^{* * *}$ \\
\hline Norway & 0.002 & 3.056 & 4.514 & -0.568 & $35.589^{* * *}$ \\
\hline Russia & -0.106 & 2.581 & 35.281 & -4.253 & $4584.200^{\text {*** }}$ \\
\hline
\end{tabular}

Table B

Correlations-independent variables. This table reports the correlation between independent variables. Explanatory variables are world market returns (world), oil futures returns (oil), currency variations against the U.S. dollar (currency) and oil volatility $\left(\hat{\sigma}_{\text {garch }}\right)$. The sample period runs from 1988:12 through 2009:06.

\begin{tabular}{lrrrr}
\hline & world & \multicolumn{1}{c}{ oil } & currency & $\hat{\sigma}_{\text {garch }}$ \\
\hline world & 1.000 & & & \\
oil & 0.104 & 1.000 & & \\
currency & 0.240 & 0.106 & 1.000 & \\
$\hat{\sigma}_{\text {garch }}$ & -0.025 & -0.056 & -0.026 & 1.000 \\
\hline
\end{tabular}




\section{References}

Adler, M., Dumas, B., 1983. International portfolio selection and corporation finance: a synthesis. J. Financ. 46, 925-984.

Aloui, C., Jammazi, R., 2009. The effects of crude oil shocks on stock market shifts behaviour: a regime switching approach. Energy Econ. 31, 789-799.

Aloui, C., Nguyen, D., Njeh, H., 2012. Assessing the impacts of oil price fluctuations on stock returns in emerging markets. Econ. Model. 29, 2686-2695.

Basher, S.A., Sadorsky, P., 2006. Oil price risk and emerging stock markets. Glob. Financ. J. 17, 224-251.

Bernanke, B.S., 1983. Irreversibility, uncertainty, and cyclical investment. Q. J. Econ. 98 85-106.

Bjørnland, H., 2000. The dynamic effects of aggregate demand, supply and oil price shocks-a comparative study. Manch. Sch. 68, 578-607.

Bjørnland, H., 2009. Oil price shocks and stock market booms in an oil exporting country. Scott. J. Polit. Econ. 56, 232-254.

Carrieri, F., Majerbi, B., 2006. The pricing of exchange risk in emerging stock markets. J. Int. Bus. Stud. 37, 372-391.

Chen, N.-F., 1991. Financial investment opportunities and the macroeconomy. J. Financ. 46, 529-554

Chen, N.-F., Roll, R., Ross, S., 1986. Economic forces and the stock market. J. Bus. 59, 383-403.

Cologni, A., Manera, M., 2008. Oil prices, inflation and interest rates in a structural cointegrated VAR model for the G-7 countries. Energy Econ. 30, 856-888.

Cong, R.-G., Wei, Y.-M., Jiao, J.-L., Fan, Y., 2008. Relationships between oil price shocks and stock market: an empirical analysis from China. Energy Policy 36, 3544-3553.

Cuñado, J., Garcia, F., 2003. Do oil price shocks matter? Evidence for some European countries. Energy Econ. 25, 137-154.

De Santis, G., Gerard, B., 1998. How big is the premium for currency risk? J. Financ Econ. 49, 375-412.

Dumas, B., Solnik, B., 1995. The world price of exchange rate risk. J. Financ. 50, 445-477.

Fama, E., 1990. Stock returns, expected returns, and real activity. J. Financ. 45, $1089-1108$

Ferderer, J., 1996. Oil price volatility and the macroeconomy: a solution to the asymmetry puzzle. J. Macroecon. 18, 1-16.

Ferson, W., Harvey, C., 1994a. An exploratory investigation of the fundamental determinants of national equity market returns. In: Frankel, J. (Ed.), The Internationalization of Equity Markets. University of Chicago Press, Chicago.

Ferson, W., Harvey, C., 1994b. Sources of risk and expected returns in global equity markets. J. Bank. Financ. 18, 1625-1665.
Gallant, A.R., Tauchen, G., 1998. Reprojecting partially observed systems with application to interest rate diffusions. J. Am. Stat. Assoc. 93, 10-24.

Hamilton, J., 1983. Oil and the macroeconomy since World War II. J. Polit. Econ. 91, $228-248$

Hamilton, J., 1996. This is what happened to the oil price-macroeconomy relationship. J. Monet. Econ. 38, 215-220.

Huang, R., Masulis, R., Stoll, H., 1996. Energy shocks and financial markets. J. Futur. Mark. 16, 1-27.

Jiménez-Rodríguez, R., Sanchez, M., 2004. Oil price shocks and real GDP growth: empirical evidence for some OECD countries. Working Paper Series, 362. European Central Bank.

Jones, C., Kaul, G., 1996. Oil and stock markets. J. Financ. 51, 463-491.

Kilian, L., 2008. The economic effects of energy price shocks. J. Econ. Lit. 46, 871-909.

Korhonen, I., Ledyaeva, S., 2010. Trade linkages and macoeconomic effects of the price of oil. Energy Econ. 32, 848-856.

Lee, K., Ni, S., Ratti, R., 1995. Oil shocks and the macroeconomy: the role of price variability. Energy J. 16, 39-56.

Litzenberger, Robert H., Rabinowitz, Nir, 1995. Backwardation in oil futures markets: theory and empirical evidence. J. Financ. 50, 1517-1545.

Mork, K., 1989. Oil and the macroeconomy when prices go up and down: an extension of Hamilton's results. J. Polit. Econ. 3, 740-744.

Mork, K., Olsen, O., Mysen, H., 1994. Macroeconomic responses to oil price increases and decreases in seven OECD countries. Energy J. 15 (4), 19-36.

Nandha, M., Faff, R., 2008. Does oil move equity prices? A global view. Energy Econ. 30, 986-997.

Oberndorfer, U., 2009. Energy prices, volatility, and the stock market: evidence from the Eurozone. Energy Policy 37, 5787-5795.

Park, J., Ratti, R.A., 2008. Oil price shocks and stock markets in the U.S. and 13 European countries. Energy Econ. 30, 2587-2608.

Pindyck, R.S., 1991. Irreversibility, uncertainty, and investment. J. Econ. Lit. 29, 1110-1148.

Ramos, S., Veiga, H., 2011. Risk factors in oil and gas industry returns: international evidence. Energy Econ. 33, 525-542.

Sadorsky, P., 1999. Oil price shocks and stock market activity. Energy Econ. 21, 449-469.

Sadorsky, P., 2003. The macroeconomic determinants of technology stock price volatility. Rev. Financ. Econ. 12, 191-205.

Schwert, G., 1989. Why does stock market volatility change over time? J. Financ. 44, 1115-1153.

Schwert, G., 1990. Stock returns and real activity: a century of evidence. J. Financ. 45 , 1237-1257.

Solnik, B., 1974. The international pricing of risk: an empirical investigation of the world capital market structure. J. Financ. 29, 365-378.

Stulz, R., 1981. A model of international asset pricing. J. Financ. Econ. 9, 383-406. 